\title{
nombalina
}

(8)

\section{Status and habitat use of waders in the Mondego estuary}

$\begin{array}{ll}\text { Autor(es): } & \text { Lopes, Ricardo; Cabral, João Alexandre; Múrias, Tiago; Pacheco, } \\ \text { Carlos; Marques, João Carlos }\end{array}$

Publicado por: Imprensa da Universidade de Coimbra

URL

persistente: URI:http://hdl.handle.net/10316.2/32676

DOI: $\quad$ DOI:http://dx.doi.org/10.14195/978-989-26-0336-0_13

Accessed : $\quad$ 26-Apr-2023 08:43:09

A navegação consulta e descarregamento dos títulos inseridos nas Bibliotecas Digitais UC Digitalis, UC Pombalina e UC Impactum, pressupõem a aceitação plena e sem reservas dos Termos e Condições de Uso destas Bibliotecas Digitais, disponíveis em https://digitalis.uc.pt/pt-pt/termos.

Conforme exposto nos referidos Termos e Condições de Uso, o descarregamento de títulos de acesso restrito requer uma licença válida de autorização devendo o utilizador aceder ao(s) documento(s) a partir de um endereço de IP da instituição detentora da supramencionada licença.

Ao utilizador é apenas permitido o descarregamento para uso pessoal, pelo que o emprego do(s) título(s) descarregado(s) para outro fim, designadamente comercial, carece de autorização do respetivo autor ou editor da obra.

Na medida em que todas as obras da UC Digitalis se encontram protegidas pelo Código do Direito de Autor e Direitos Conexos e demais legislação aplicável, toda a cópia, parcial ou total, deste documento, nos casos em que é legalmente admitida, deverá conter ou fazer-se acompanhar por este aviso.

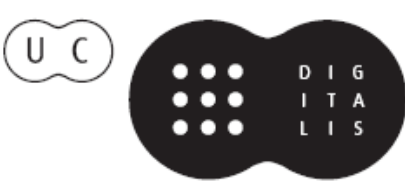


MIGUEL ÂNGELO PARDAL JOÄO CARLOS MARQUES MANUEL AUGUSTO GRAÇA Scientific Editors

\section{Aquatic Ecology of the Mondego River Basin Global Importance of Local Experience}




\author{
MIGUEL ÂNGELO PARDAL \\ JOẢO CARLOS MARQUES \\ MANUEL AUGUSTO GRAÇA \\ Scientific Editors
}

\title{
Aquatic Ecology of the Mondego River Basin Global Importance of Local Experience
}




COORDENAÇÃO EDITORIAL
Imprensa da Universidade de Coimbra
CONCEPÇÃO GRAFICA
António Barros
INFOGRAFIA
António Resende
Estimulus [design] • Coimbra
EXECUÇÃO GRAFICA
GRAFIASA
ILUSTRAÇÃO DA CAPA
P. P. Cunha e ]. Dinis
ISBN
972-8704-04-6
DEPOSITO LEGAL
I75038/02

(C) JANEIRO 2002, IMPRENSA DA UnIVERSIDADE DE COIMBRA

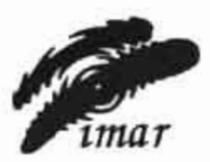

CPIMAR

imar

OBRA PUBLICADA COM O PATROCINIO DE:

IMAR - INSTITUTO DO MAR

IPIMAR - INSTITUTO DE INVESTIGAÇĀO DAS PESCAS E DO MAR 



\author{
RICARDO LOPES ' \\ JOĀo ALEXANDRE CABRAL ' \\ TIAGO MÚRIAS ' \\ CARLOS PACHECO ' \\ JoÁo Carlos Marques'
}

\title{
STATUS AND HABITAT USE OFWADERS INTHE MONDEGO ESTUARY
}

\begin{abstract}
This paper describes the status and habitat use of the wading birds community at the Mondego estuary. Special emphasis is given to trends of population size and the importance of major habitats for waders. intertidal mudflats and salinas. Dunlin Calidris alpina is the most important species in terms of numbers but more 29 other species also occur. Numbers of some important species have been decreasing during last years (e.g. Avocet Recurvirostra avosetta) while for other species an increase was detected (e.g. Black-winged Stilt Himantopus himontopus). The Mondego wader assemblage is relatively important in the whole Portuguese wintering community (between 1.1 and $2.4 \%$ of the national totals during 1994-97). The main threat for wader conservation in the estuary is habitat loss, especially due to destruction or degradation of the preferred supratidal habitat.
\end{abstract}

\section{Introduction}

Estuaries are well known ecosystems with diversified and important bird communities (McLusky 1989). Since the order Charadriiformes (including waders, gulls and terns) and in particular the suborder Charadrii (waders) has a very important role on most of the estuarine trophic chains (Moreira 1997), this determined the focus of ornithological inyestigation during last decade in the Mondego estuary. The Mondego estuary $\left(40^{\circ} 08^{\prime} \mathrm{N} 8^{\circ} 50^{\prime} \mathrm{W}\right.$, fig. I) along with other portuguese estuaries (Tagus, Sado and Minho) and rias (Aveiro and Formosa) supports a large number of aquatic birds, due to the existence of suitable supratidal habitats and an important intertidal benthic macroinvertebrate community (Marques et al. 1993. Flindt et al. 1997. Múrias et al. 1997).

While the estuary has been recognised as one of the major wintering sites in Portugal for Lesser Black-backed Gull (Lorus fuscus). for other species its importance

(1) IMAR - Instituto do Mar. Centro Interdisciplinar de Combra. Departamento de Zoologia. Universidade de Coimbra, 3004-517 Coimbra. Portugal 
was more difficult to assess. Exploratory wader mid-winter counts in the Mondego estuary were first performed in 1977 and 1978 (Rufino 1979) to evaluate the major habitats for coastal waders in Portugal. Since these census did not reveal important numbers of waders, the Mondego estuary was excluded from the national mid-winter wader census in the following years. In 1986 the estuary was again included, but less than 300 birds were counted (Rufino and Neves 1986). Between 1986 and 1993. several mid-winter census were performed (Múrias, unpublished work; Rufino 1989.1990 ) but the number of birds counted never reached the threshold of 1000 birds, due mainly to incomplete coverage of the estuary and misrepresentation of several key species. Therefore, an accurate determination of wader abundance was still unavailable by 1993, and the quality of previously collected data prevented any further interpretation.

The main objective of this work was to assess the current knowledge about bird communities in the estuary, to clarify the importance of Mondego estuary for waders and to present data on seasonal and annual variation in wader numbers and use of main estuarine habitats (intertidal areas and salinas). This will provide a comprehensive framework for research and conservation of waders at Mondego Estuary.

\section{Methods}

Bird community

Studies on the whole bird community of Mondego estuary began in 1993. when during the whole year a monthly census was performed, comprising transects throughout the most common habitats (Pacheco, unpublished work). This study recorded the presence of species but no density estimates were performed at that time. Apart from this census, during the last decade several species were also added from observation records.

Wader populations

From October 1993 to May 1995, fortnight low-tide and high-tide counts were performed by Múrias (1997), providing the first accurate census of wader abundance. From January 1996 onwards, Lopes (1999. unpublished work) implemented a 220 fortnightly (1996) and monthly (1997-1999) low-water census, with the main objective of providing information about trends on the abundance of the major species of waders.

The census carried by Múrias (1997) covered the south arm and most of the salinas of Murraceira island (fig. 1).The mudflats were surveyed during spring tides from three fixed points while a transect was used to survey the supratidal habitats (salinas, fish farms and saltmarshes). Most of the censuses were performed in one day. After 1996 the coverage was even more extended with the inclusion of the salinas of the south-arm and the mudflats in the north arm by Lopes (1999). 


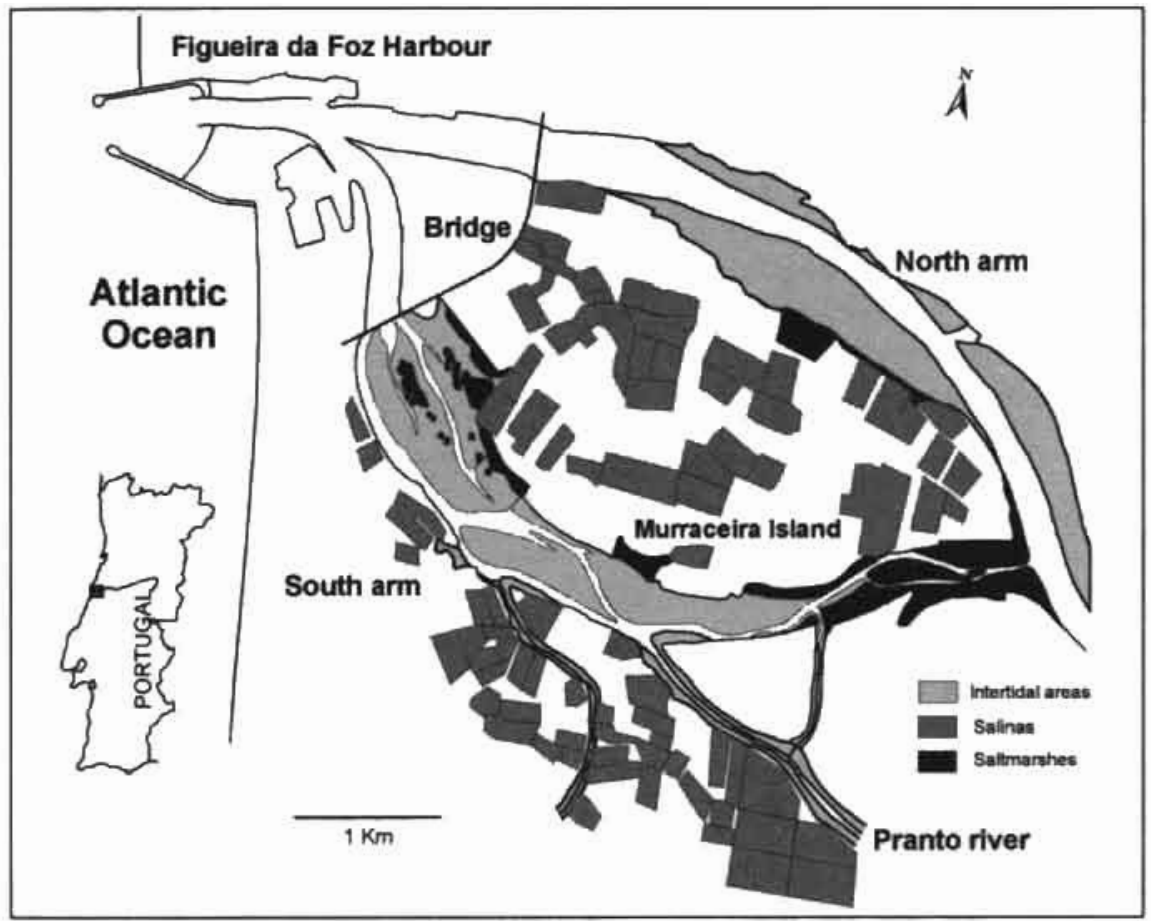

Fig. 1. The Mondego estuary with the two main habitats for waders, intertidal areas (light grey) and salinas (medium grey). The converted or abandoned salinas where the degradation is still reversible are also represented.

In order to allow for comparisons of results, the fortnight census were averaged by month for each species. The few missing censuses were interpolated by calculating the average of the two nearest census made before and after the missing data (Wolff and Smit 1990). Unfortunately, a gap of six months occurred between the census carried by Múrias (1997) and the beginning of the present census program (Lopes 1999). However both census were analysed together in order to provide a longer time-series for interpretation, but no missing values and trend analysis were performed at this stage,

Trends in use of habitat

The census performed by Múrias (1997) and Lopes (1999) discriminated the number of birds in these two types of habitat and the proportion of birds in each type of habitat was calculated. In fortnight counts the average monthly proportion of birds in salinas was used. However, since the number of salinas covered by the first census (1993-1995) was lower, not including south arm salinas, the pattern of use may be biased so it wasn't included in the analyses, which used only data from 19961999. 


\section{Results and discussion}

\section{Bird community}

The results confirmed the high bird diversity of Mondego estuary, with 137 bird species recorded in the estuary during last decade. The bird community in Mondego estuary was dominated by two main orders (Passeriformes and Charadriiformes) with 35 and $31 \%$ of the species (fig. 2). However, most of the species used the estuary as migratory and wintering ground and only 18 species were confirmed breeders. Other 35 species still need to be confirmed as breeding in the estuary.

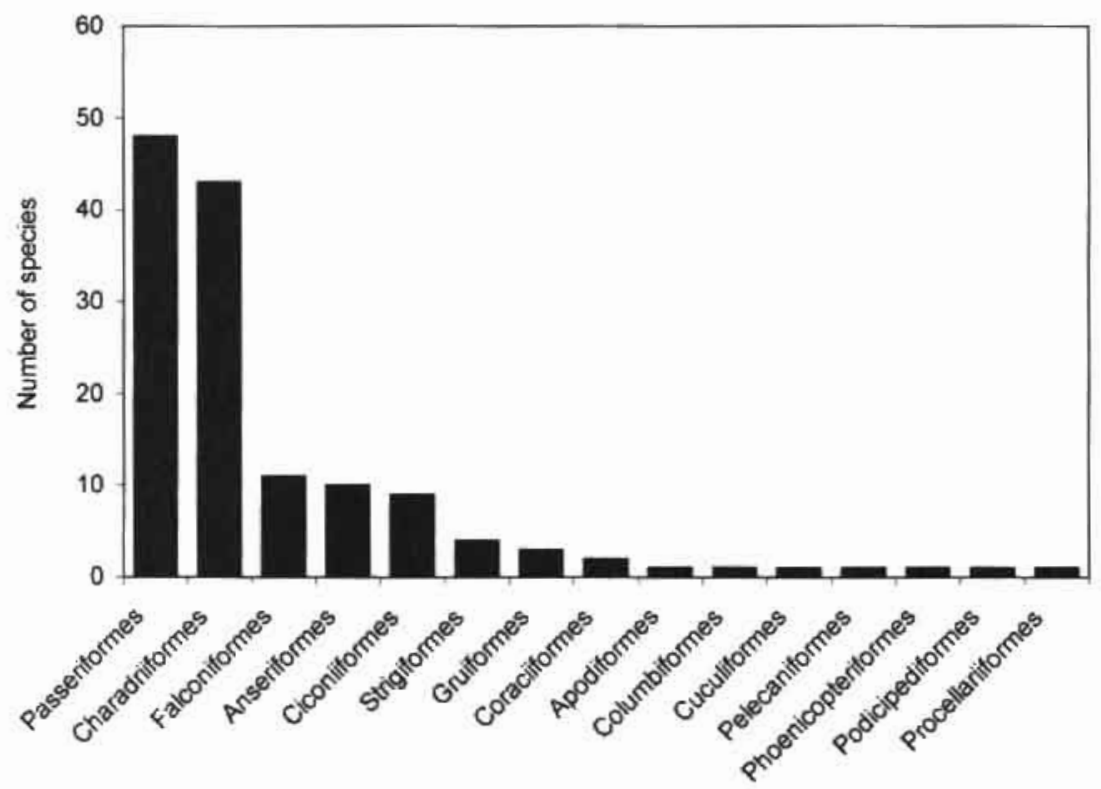

Fig, 2. Number of bird species grouped by order, recorded during the 1990 's in the Mondego estuary.

Wader species composition and relative abundance

From 1993 to 2000 were recorded 30 species of waders (appendix 1). The number of species recorded monthly seemed to increase from 1993-1995 to the period 1996-1999. probably due more to inter-observer variability than to a real trend. The maximum of birds occurred during winter months, especially in December and January (fig. 3). A second peak was observed in April-May (pre-nuptial migration) while another peak occurred from August to October (post-nuptial migration). During summer a maximum of few birds were present in the estuary (mainly breeding birds). 

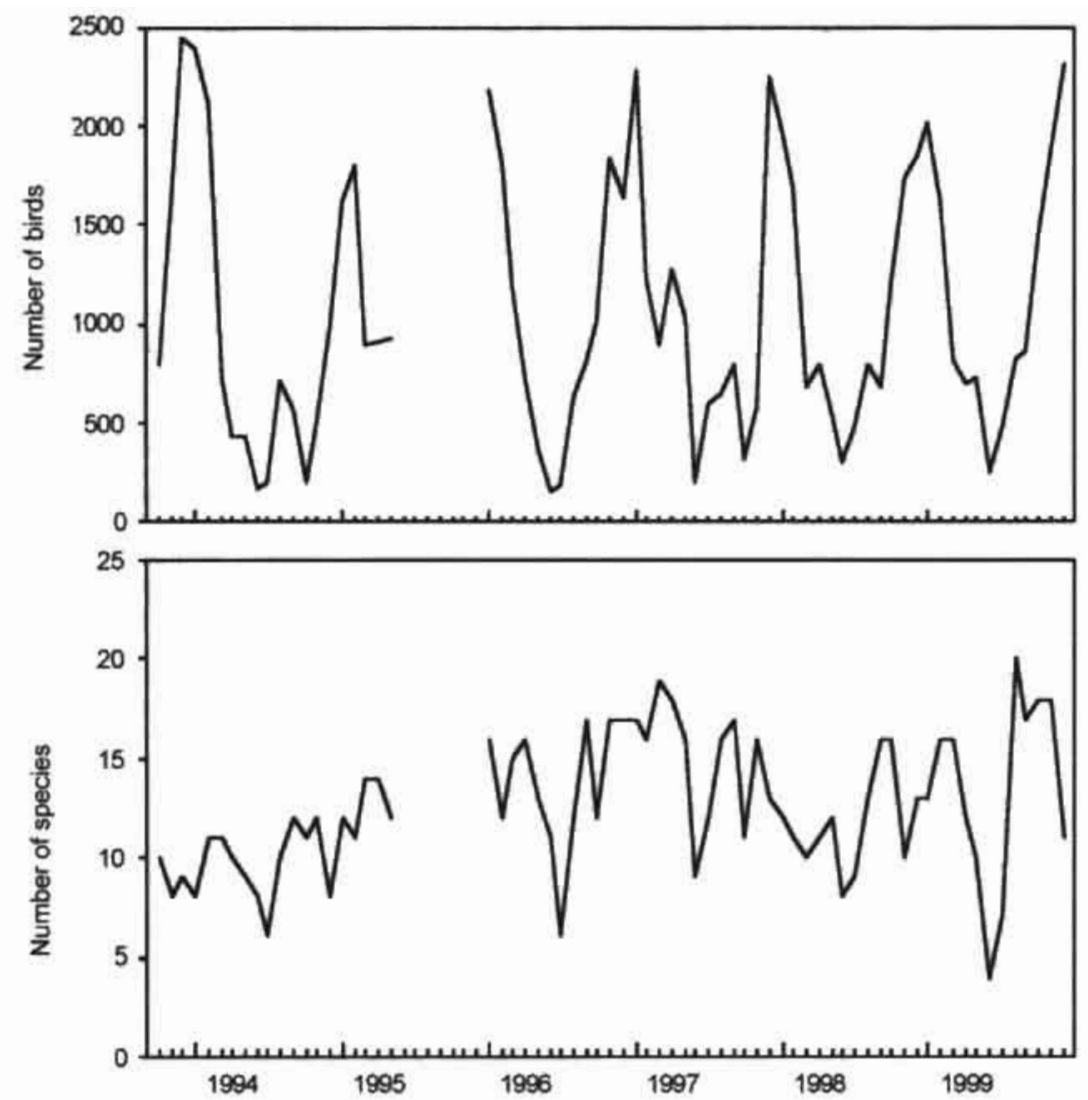

Fig 3. Number of waders and species that were observed in low tide census from October 1993 to December 1999. (Data from Múnas 1977. Múrias et al. 1997: Lopes 1999, unpublished data),

Six species (fig. 4) represented a large proportion of the wader assemblage (mean monthly percentage $=89 \%$ ). The community was dominated by Dunlin Calidris alpina and Avocet Recurvirostro ovosetto during winter (November-February). In summer (June-July) the Black-winged Stilt Himantopus himantopus and Kentish Plover Charadrius alexandrinus were the most important species. During both migration periods Dunlin was the dominant species but high number of Kentish Plovers and Ringed Plover Charadrius hiaticula were also present.

The wader assemblage of the Mondego estuary did not differ much from other estuaries in Portugal (Múrias 1997). Dunlin is also the main species for most of the sites along southwest European coast (Cramp and Simmons 1983, Smit and Piersma 1989). Portugal is one of the countries with highest number of wintering avocets (Smit and Piersma 1989) and they were also one of the most important species in the estuary. 


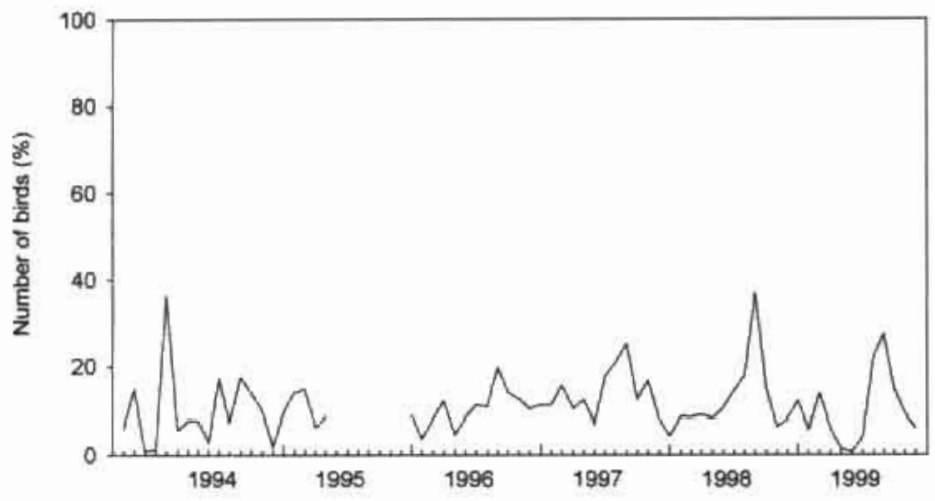

Fig. 4. Proportion of the six most abundant important species in the estuary (Dunlin. Avocet and Grey Plover, Kentish Plover, Ringed Plover and Black-winged Stitt) that were observed in low tide census from October 1993 to December 1999.

Important species

Dunlin was the most abundant wader species in the estuary in most of the counts (fig. 5). It was usually more abundant during winter with a smaller peak count in spring due to the passage of migrating birds. During autumn migration (August-October) an increase was observed, corresponding to a more continuous passage of birds than in spring migration. Ringing data during autumn migration suggest the occurrence of differential migration between adults and juveniles, with a very low percentage of adults in September (Lopes 1999, unpublished data).

The Avocet was the second most abundant species (fig, 5). It was a typical wintering species, found from October to March, but the number of avocets wintering in the estuary decreased during last years. Most of the colour-ringed birds observed in the estuary came from Germany and Holland, although a ring recovery was also found from Denmark. Since the majority of these birds were ringed as pulli or breeding, we can be confident that most of them breed in those countries.

Grey Plover Pluvialis squatarola was another important wintering species with a very typical seasonal pattem (fig. 5 ). It differed from the avocet since some migrating 224 birds were also present during spring and autumn passage. There was an increase in the number of wintering birds in recent years while no trend was observed for migrating birds.

The Kentish Plover was present throughout the year (fig. 5) and was also one of the three species that bred in the estuary, along with Black-winged Stilt and Redshank Tringo totonus. Its seasonal pattern is very difficult to interpret due to the existence of several distinct populations (breeding, wintering and migrating birds).

Another species with a typical pattern was the Ringed Plover (fig. 5). The highest numbers occurred during autumn migration with a continuous decrease during the 

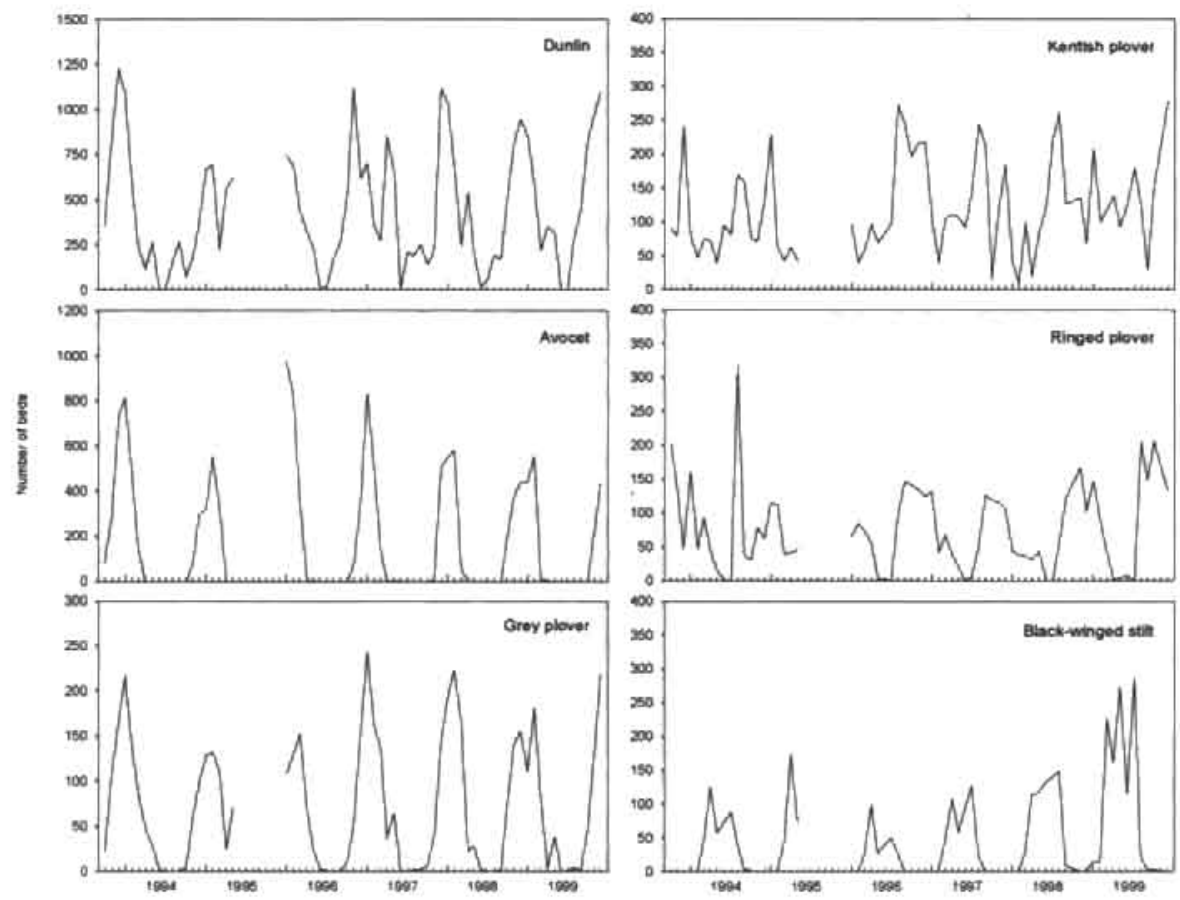

Fig. 5. The nurnber of birds for the six most abundant species that were observed in low tide census from October 1993 to December 1999.

winter and a smaller peak during spring migration. The absence of this pattern during 1993-1995 was probably due to inter-observer variability than to a real trend. In 1998 1999 the number of Ringed Plovers that use the estuary during autumn migration increased while during spring their number decreased substantially.

The black-winged Stilt has been increasing in the Mondego estuary (fig. 5). During April a peak occurred due to the presence of a large number of birds including the local breeding population and migrating birds. The observation of colour-ringed birds showed that the estuary was used as a stopover for migratory birds breeding in France and Spain. In the last years some birds were present during some part of the winter. These observed seasonal patterns did not differ from those observed in other Portuguese estuaries (Batty 1992, Encarnação 1993).

Trends in wintering populations of waders

The mid-winter counts have been adopted to estimate population sizes of waders along the east-Atlantic flyway, assuming that inter-site movements are minimal (Prater 198I). In Portugal these censuses have been performed in the major estuarine areas, including Mondego. The January census performed by Múrias (1999) and Lopes (1999. unpublished work) have been incorporated in the national mid-winter wader 

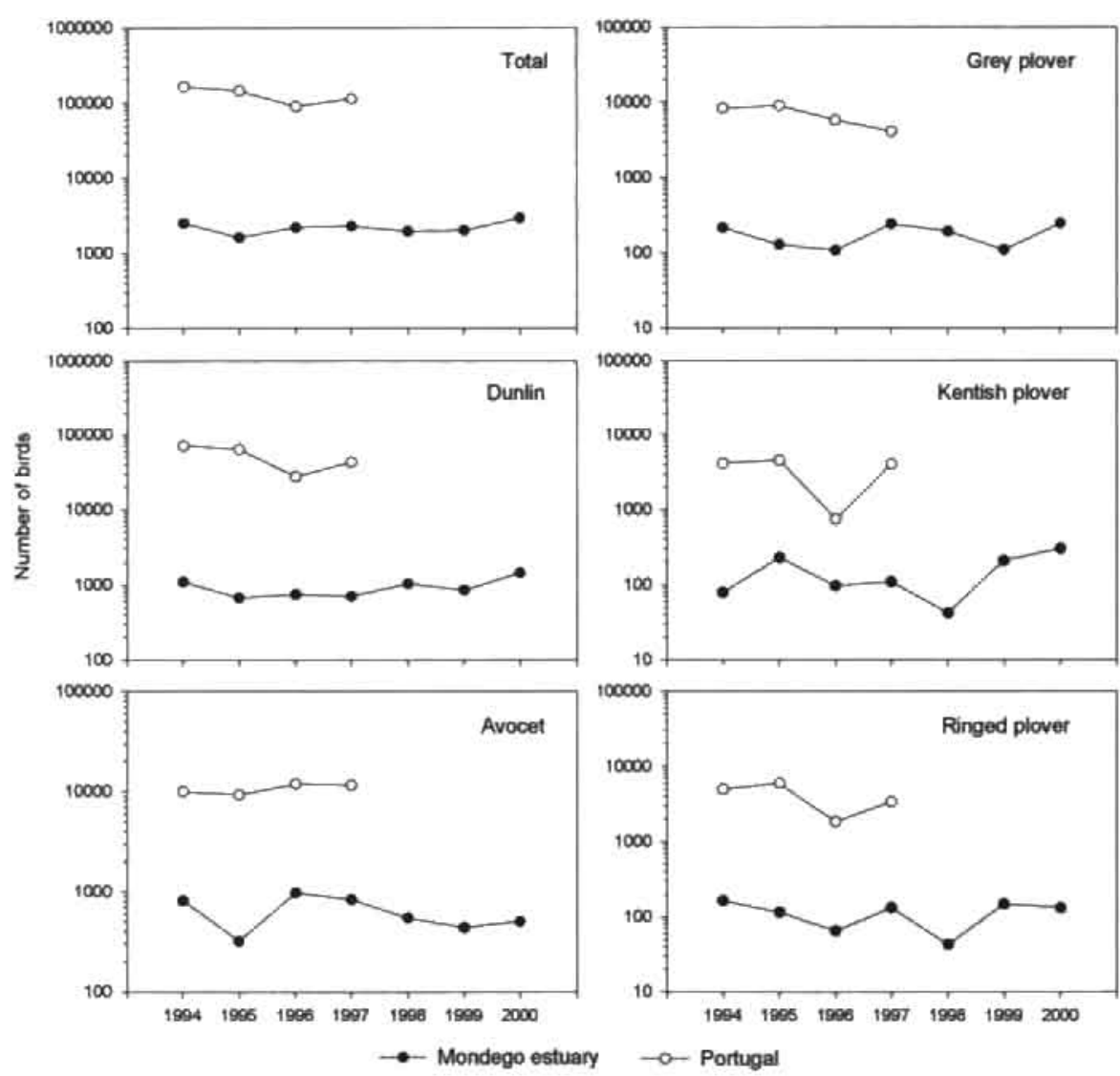

Fig. 6. Number of birds observed in the mid-winter national census and in the Mondego estuary from 1994 to 2000. Shown are total number of birds for all species and for the six most abundant species in the estuary (Dunlin, Avocet .Grey Plover Kentish Plover, Ringed Plover and Black-winged Stit).

census since 1994 (Costa and Rufino 1994, 1996a, 1996b, 1997), providing accurate information about the trends of wintering bird populations in the Mondego estuary and their national importance.

For same species there has been a trend of increase of birds during the last years (small in Dunlin and higher in Kentish Plover). This also occurred slightly for the total 226 number of birds (fig. 6). Grey Plover and Ringed Plover exhibited a fluctuation between years with no discernible trend while avocets showed a negative trend in the last years with a recent stabilisation in numbers.

Unfortunately at this time no national data is available for the last three years. According to Farinha and Trindade (1994) the Mondego estuary supported less than $0,5 \%$ of wintering waders in Portugal during 1989-92. We think that this was due more to a deficient coverage of the area than to real estimates. The total numbers in the Mondego estuary represented between 1.1 and $2.4 \%$ of the national totals during 1994-97. which seems a more representative figure of the importance of the estuary 
as a wintering site. For some species this proportion is much higher. In national terms the wintering population of avocets in the Mondego estuary was for most of the years, an important proportion of the total number of avocets in Portugal (3.4 to 8.2\%). Grey Plover ( 1.4 to $5.9 \%$ ), Kentish Plover ( 1.9 to $12.9 \%$ ) and Ringed Plover (1.9 to $3.6 \%$ ) were also well represented in the Mondego estuary. This relative importance was probably the reason for the existence of correspondence in the fluctuations on the total numbers of Avocet, Kentish plover and Ringed plover between Mondego and Portugal as a whole (fig. 6). For the total values, Dunlin and Grey plover no correspondence was found.

Trends in use of habitat

Waders use several kinds of habitat in the Mondego estuary, including intertidal mudflats, salinas, aquaculture ponds and rice fields (Múrias 1997, Lopes 1999). However, during low-tide periods, waders use two main types of habitats (intertidal areas and salinas). Intertidal mudflats and sandflats ( $227 \mathrm{ha}$ ) occur in both arms of the estuary and during last decade the area of intertidal habitat increased with the formation of new mudflats and sandflats in the north arm (fig. 1). Seasonal intertidal macroalgal blooms (mainly Enteromorpha spp.) have occurred in both arms during the last decade (Marques et al. 1993, Flindt et al. 1997, Marques et al. 1997, Martins et al. 1997, Pardal 1998, Lillebø et al. 1999), probably due to an increase of nutrients in the estuary, which supports industrial activities and aquaculture and receives nutrients from 15000 ha of cultivated land (mainly rice fields). This problem is described further in other articles of this book The salinas (251 ha in 1995) are located in the Murraceira island and in the left margin of the south arm and a considerable number has been abandoned or converted in the last decades. This conversion can be irreversible, with the construction of fish farms or reversible when they are used as fishponds without the destruction of the pans.

The results indicated a seasonal variation in the use of intertidal areas and salinas during low-water periods (fig. 7). During winter the proportion of birds that used salinas was very low. This was mainly due to the presence of two wintering species (Avocet and Grey Plover) that didn't use the salinas very often during low-tide. However, this proportion increased during recent years. During summer, because most species breed in the salinas (Black-winged Stitt, Redshank and Kentish Plover) the proportion of birds using salinas during low-tide was very high. The importance of salinas during migrations has changed throughout years but most of the times it showed an intermediate importance between summer and winter.

It seems that during low-tide salinas are used as complementary feeding areas during winter and migration periods, which also occurs in other estuaries (e.g. Ria Formosa, Cadiz bay) with salinas (Rufino et al. 1984, Batty 1992, Perez-Hurtado and Hortas 1993). However, during winter most of these sites support a higher proportion of birds in salinas (Batty 1992, Perez-Hurtado and Hortas 1993). Since these areas also support a higher number of waders, the competitive pressure on mudflats may be higher than in Mondego estuary, forcing birds to move to alternative supratidal habitats. The salinas of Mondego are very small (average size $=4 \mathrm{ha}$ ), which may contribute for 


\section{References}

Batty, L 1992.The wader communities of a saline and an intertidal site on the Ria Formosa Wader Study Group Bulletin, 66: $66-72$

Costa, LT. and Rufino, R 1994. Contagens de aves aquáticas em Portugal- Janeiro de 1994. Airo 5(1):8-16.

Costa, LT. and Rufina, R. 1996a. Contagens de aves aquáticas em Portugal - Janeiro de 1995. Airo 7(1):36-43.

Costa, LT. and Rufino, R. 1996b. Contagens de aves aquáticas em Portugal - Janeiro de 1996. Airo 7(2):69-76.

Costa, LT. and Rufino, R 1997. Contagens de aves aquáticas em Portugal - janeiro de 1997. Airo 8(1/2):25-32

Gamp, S. and Simmons. K 1983. The Birds of Western Paiearctic. Vol. III, Waders and Gulls. Oxford University Press.

Encarnação, V. 1993. Recenseamento de limicolas no Parque Natural da Ria Formosa Airo, 3:67-68.

Farinha, /C and Trindade. A 1994. Contribuição para o inventánio e caracterização de zonas húmidas em Portugal, Publicação MedWet / Instituto da Conservação da Natureza.

Findt, M.R. Kamp-Nielsen, L, Marques, J.C., Pardal, MA, Bocci, M., Bendoricchio, G, Salomonsen, J., Nielsen, S.N. and Jorgensen. S.E. 1997. Description of the three shallow estuaries: Mondego river (Portugal), Roskilde Fiord (Denmark) and the Lagoon of Venice (italy). Ecol. Model. 102, 17-31.

Lillebø.A._.Pardal, MA and Marques, J.C. 1999. Population structure, dynamics and production of Hydrobia ulvoe (Pennant) (Mollusca: Prosobranchia) along an eutrophication gradient in the Mondego estuary (Portugal). Acta Oecol, 20, 289-304.

Lopes, R.. 1999, Impacto das aves limicolas sobre os macroinvertebrados nas áreas intertidais do estuário do Mondego (Portugal). Tese de Mestrado, Universidade de Coimbra.

Marques, J.C. Rodrigues, LB, and Nogueira, A.A, 1993. Intertidal macrobenthic communities structure in the Mondego estuary (Westem Portugal): Reference situation. Vie Milieu 43(2-3), 177-187.

Marques. J.C. Pardal, M.A. Nielsen, S.N. and Jørgensen, S.E., 1997. Analysis of the properties of exergy and biodiversity along an estuarine gradient of eutrophication. Ecol. Model. 102, 155-167.

Martons, L. Marques, JC. Jergensen S.E and Nielsen. S.N. 1997. Modelling the effects of green macroalgae blooms on the population dynamics of Cyothuro corinoto (Crustacea isopoda) in a eutrophied estuary Ecol. Model. 102, 33-53.

Mclusky, DS. 1989. The Estuanine Ecossystem. 2nd ed. Chapman \& Hall, New York

Moreira, F. 1997. The importance of shorebirds to energy fluxes in a food web of a south european estuary, Estuar. Coast. Shelf Sci. 44:67-78.

Murias, T. 1997. Effects of habitat loss on waders (Aves, Charadrii) in the Mondego Estuary (Portugal). Tese de Doutoramento, Universidade de Coimbra.

Múrias, T, Cabral, JA, Lopes, RJ. and Marques, J.C. 1997. Low-water use of the Mondego estuary (West Portugal) by waders (Charadrii). Andeola 44 (1): $79-91$.

Pardal, MA, 1998. Impacto da eutrofização nas comunidade macrobentónicas do braço sul do estuário do Mondego (Portugal). PhD Thesis. Universidade de Coimbra.

Perez-Hurtado. A and Hortas. F, 1993. Actividad trofica de limicolas invernantes en salinas y cultivos piscicolas de la Bahia de Cadiz. Doñana, Acta Vertebrata. 20 (2): 103-123.

Prater. A. 1981. Estuary birds of Britain and ireland.T \& A D Poyser, Caiton.

Rưfino, R 1979. Limicolas em Portugal. Publicaçōes CEMPAVSEA Lisboa.

Rufino, R 1989. Contagens de aves aquáticas - Jan/Fev 1989. SNPRCN, CEMPA Lisboa

Rufino, R 1990. Contagens de aves aquáticas - Inverno de 1987 e 1990. SNPRCN. CEMPA Lisboa.

Rufino, $R$ and Neves, $R$ 1986, Contagens de aves aquáticas - janeiro de 1986. Publicaçōes CEMPAVCEA Lisboa

Smit. C.J. and Piersma T. 1989. Numbers, midwinter distribution and migration of wader populations using the East Atlantic flyway, in Boyd. $\mathrm{H}$ and Pirot, ...H, (eds). Ayways and Reserve Networks for waterbirds. MRB Special Publication 9: 24-63.

Wolf, Wf. and Smit. C.J. 1990. The Banc d'Anguin, Mauritania, as an envinonment for coastal birds. Andea $78(1 / 2)$ : $17-38$. 


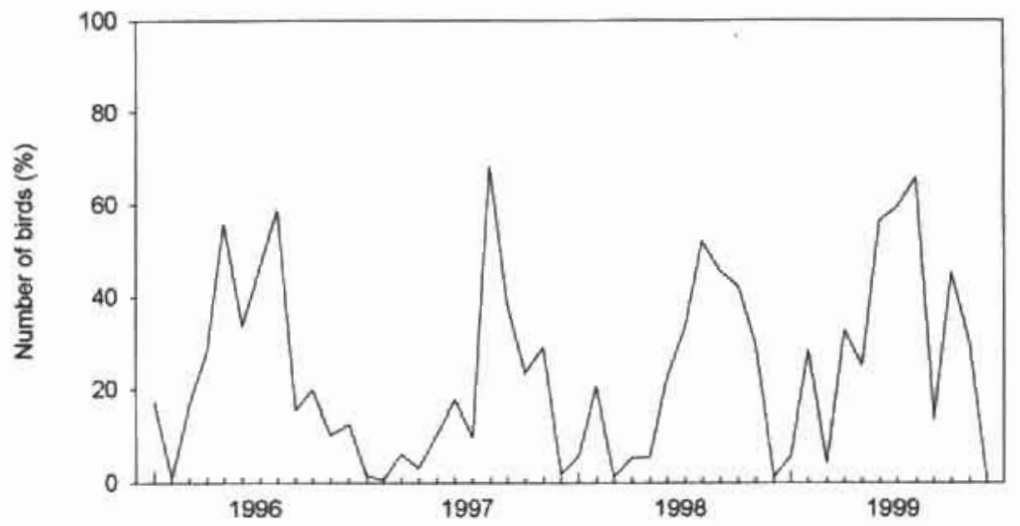

Fig. 7. Proportion of burds observed in salinas during low tide census from January 1996 to December 1999.

a larger variation in physical factors such as water depth and presence of vegetation. This variation is usually higher during winter decreasing the area of salinas available for feeding by waders. During summer salinas are very important because they constitute the preferred waders' habitat for breeding. Despite the ongoing conversion of salinas, some species such as the Black-winged Stilt have increased, presumably because they may prefer salinas with both abandoned and active sections, providing not only food but also camouflage and shelter from predators.

\section{Conclusions}

This review managed to compile most of the available data on wader bird communities in the Mondego estuary. Information is provided on seasonal and annual patterns of variation of bird numbers. These results are very important to understand the dynamics of wader populations in Mondego, Portugal as a whole and for the conservation of Mondego estuary. Despite the small area and human pressure, the Mondego estuary still holds an important and diversified wader community. This situation may change in the future if the degradation or destruction of the main habitats is not arrested.

\section{Acknowledgements}

We would like to thank all the people that helped in the collection of the data throughout these years. 


\section{Appendix 1}

List of wader species recorded in the estuary during this work.

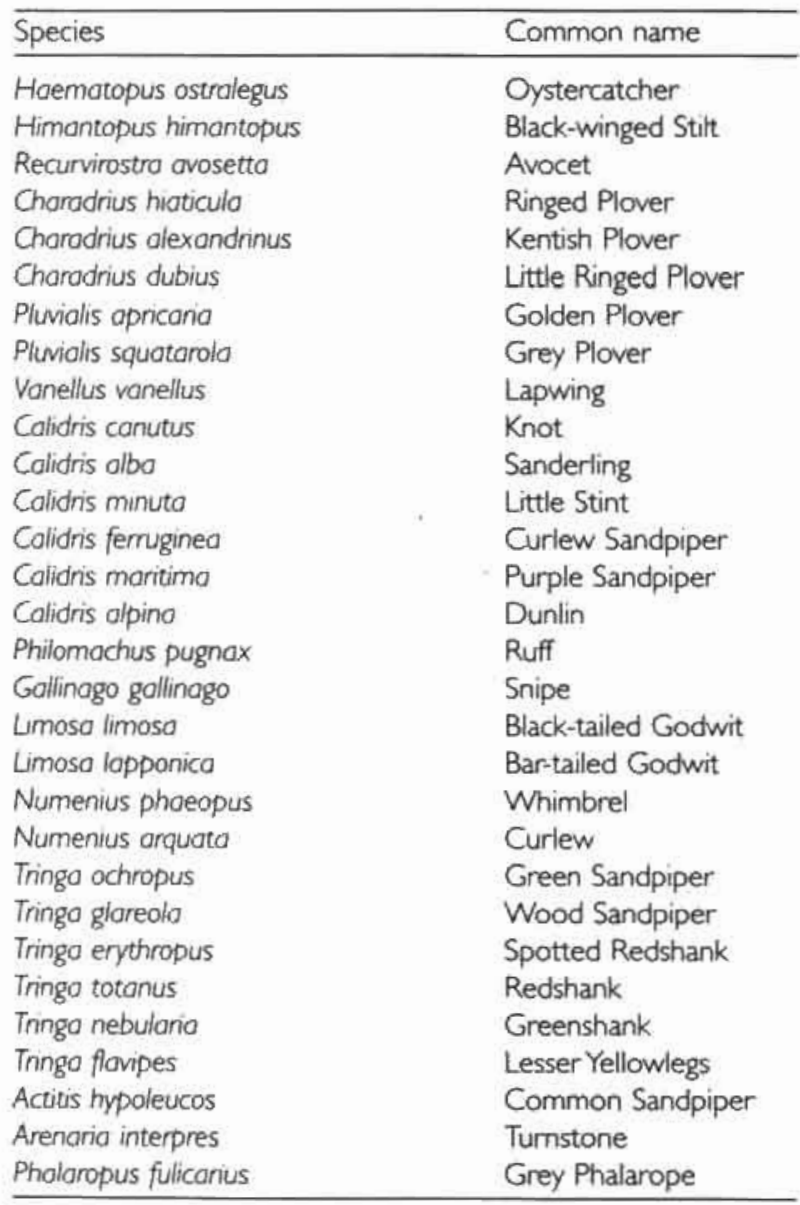


(Página deixada propositadamente em branco) 
Série

Investigação

$\bullet$

Coimbra

Imprensa da Universidade

2002 